\title{
Staroverstvo - the Old Religion - the Slovene Pre-Christian Religion
}

\author{
Anton Perdih \\ Correspondence: Faculty of Chemistry and Chemical Technology, University of Ljubljana, SI-1000 Slovenia (retired)
}

Received: April 12, 2021 Accepted: May 14, 2021 Online Published: May 18, 2021

doi:10.5539/res.v13n2p114

URL: https://doi.org/10.5539/res.v13n2p114

\begin{abstract}
The data about staroverstvo, i.e. about the pre-Christian religion in three regions in Slovenia are reviewed. The most archaic of them is the Posoško staroverstvo - the Old Religion around the upper Soča River valley. For it is characteristic the single, female god, the Great Mother, a number of spirits, importance of triangular features, rocks, caves, stone and wood, way of life in peace, reincarnation of souls. The Kraško staroverstvo - the Old Religion in the Karst region is intermediate between it and the East Slavic pre-Christian religion. The influence of the arrival of agriculture about 7,500 years ago is indicated in it. The Dolenjsko staroverstvo - the Old Religion in Western Lower Carniola reflects the Iron Age situation. Characteristic for it is the revering of waters as well as the bird-hills close to hill-forts. The hill-forts started to be erected on the intrusion from east of the Y chromosome haplogroup R1b people about 6,500 years ago. The bird-hills served the birds, which would carry the soul of the deceased into the other world, possibly onto the other side of the moon. All these Old Religions indicate that the ancestors of Slovenes did not arrive in the $6^{\text {th }}$ Century AD from east of the Carpathian Mountains but were aboriginal in Slovenia.
\end{abstract}

Keywords: bird-hills, goddess, Great Mother, hill-forts, reincarnation, spirit, stone age, triangular features

\section{Introduction}

The state Slovenia is in Europe, "between Venice and Vienna". The Slovenes have a rich and diverse folk tradition. This speaks among others about the male beings (divji mož, ajd, velikan, škrat, povodni mož, pasjeglavec, volkodlak, etc.) [Engl. translation: wild man, heathen, giant, dwarf, water sprite, dog-head human, werewolf, wolfman, etc.], the female beings (divja baba, baba Pehtra, krivopeta, Torka, vesna, vila, žalik žena, rojenica etc.) [Engl. translation: wild hag, hag Pehtra, bandyheel, Torka, Vesna, villa, nymph, the Fates etc.], the games of tag, and dancing games that would have originated in the Paleolithic; as well as about the tools and accessories from a time before the Roman occupation, etc., (Baš, 2004).

The Slovene folk tradition speaks about the "wild men" who lived at higher altitudes, i.e. on a hill or a mountain; see e.g. Šavli (2008a,b). It appears that these "wild men" were hunters/gatherers, while the "wild hags" were gatherers, and they spoke a language, which was similar to that spoken by the agriculturists in the valleys. According to the Slovene folk tradition, they were able to communicate about very detailed things.

In addition to this diverse folk tradition there are becoming known also the local versions of the old, i.e. the pre-Christian Slovene religion.

\section{Dolenjsko staroverstvo [The Pre-Christian Religion in the Region of Dolenjska] - Bird-Hills Close to Hill-Forts}

Sever $(2003,2004,2008,2009,2013$, 2017) presented the remnants of the pre-Christian way of life and religion in the region of Dolenjska [Lower Carniola], i.e. in the central and southeastern Slovenia - the yellow part on the Map 1. During his over 30 years lasting field research in the region of Zahodna Dolenjska [Western Lower Carniola], contacting over 5000 inhabitants of the region, he collected the traces of the pre-Christian religion, which survived there the World War II and were gradually disappearing.

One of the characteristics of this pre-Christian religion was the revering of waters, i.a. the sources Trmožnik [Three-men-source]. The people were using the healing abilities of the holy waters well into the $20^{\text {th }}$ Century AD. Another characteristic was the believing that the birds, especially the cranes, carry the souls of the deceased into the sky, for example onto the other side of the moon. In this respect there is characteristic the often appearance of pairs of hills, i.e. of gradišča [hill-forts] and nearby tičnice [bird-hills].

There are known in Slovenia more than 200 hill-forts (gradišče) and more than 200 bird-hills (Tičnica, Tičn'ca, Tičistan, Tičerca, Tičnik, Tičevo, Na tičnici, Tičjak, Tičjek, Križ na tičnici, Ptičjek, Za tičnico, etc). The currently known ones are on the Map 1 (Sever, 2013). A number of them are also on the map of Slovenia $(1: 25,000)$. Some of them are in old cadasters, as well. 


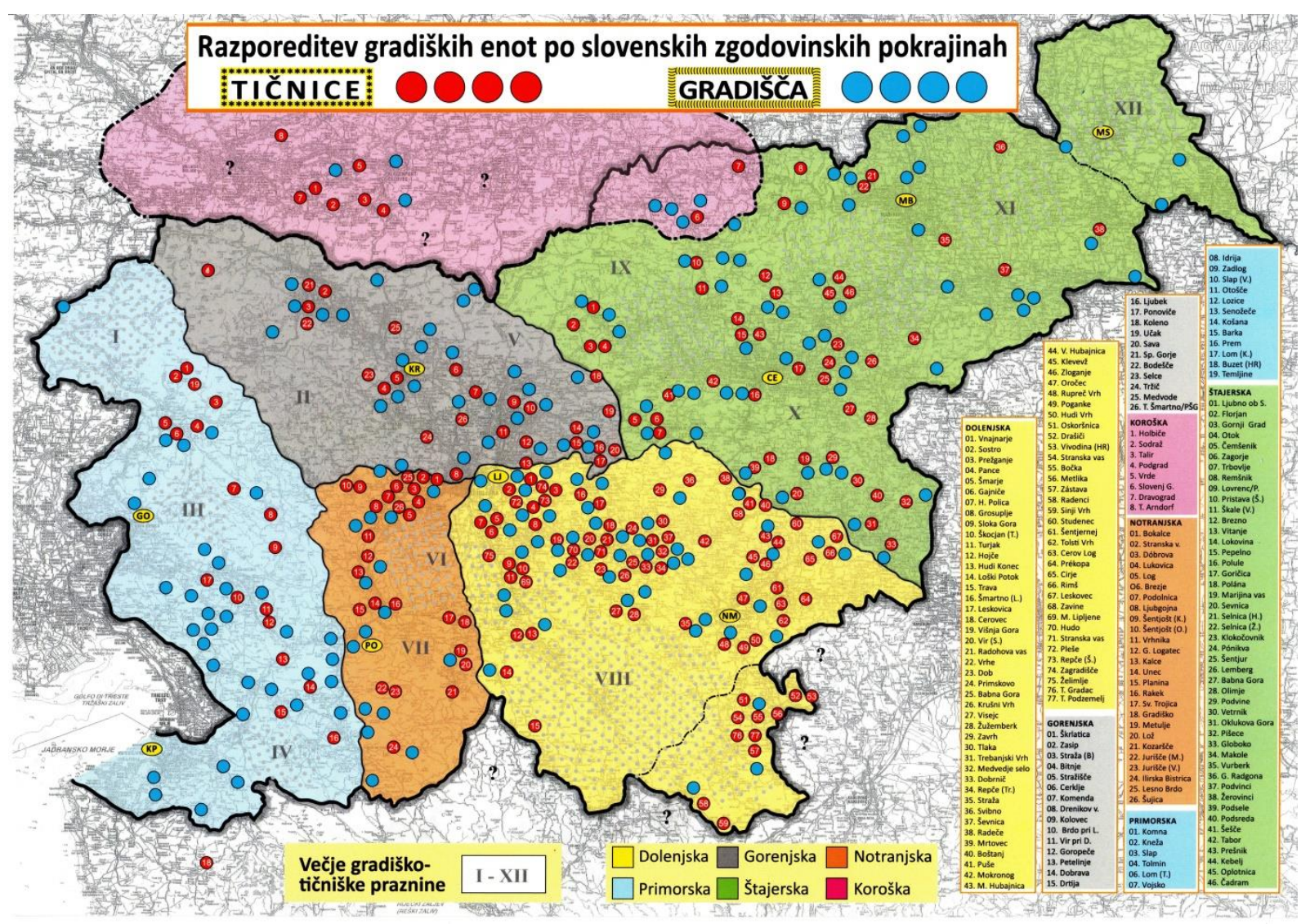

Map 1. Sever's (2013) map of gradišča [hill-forts] (blue circles) and tičnice [bird-hills] (red circles) in the historical Slovene regions in Slovenia and southern Austria

Sever (2013) presented also the details of the characteristics of a number of tičnice. One of the characteristics of several tičnice was a trapezoid shape confined by stones or by a flat ditch and in it a short alley of topped hornbeam (white beech) trees on which the birds could easily nest. In the center of some tičnice there was traced a buža, the support where the deceased was placed. There, they exposed the deceased to birds so that the birds could carry the soul of the deceased into the sky.

About the hill-forts in Slovenia there exist also other reports, for example those collected in the publication Gradišc $a v$ zahodni in osrednji Sloveniji [Hill-forts in the Western and Central Slovenia], and in it i.a. that by Turk (2018).

\section{Posoško staroverstvo - The Pre-Christian Religion in Posočje}

Posoško staroverstvo - the Old (pre-Christian) religion around the Soča River valley in western Slovenia at the present border with Italy practiced as late as around 1970 AD. The research of the still existing traces of it continues. This area is on the Map 1 in the light blue area above the sign GO in the yellow ellipse. The most comprehensive reports about it presented Medvešček $(2006,2014-2016)$ and the research continue besides other researchers the members of the Matjar society as well.

Medvešček (2015) collected the oral tradition and sacred objects, mainly stones, referring to the (pre-Christian) staroverstvo [Old Religion] in the westernmost Slovenia, at the upper Soča River valley. To him were disclosed only some parts of this religion relating to males, whereas he was mainly not entrusted about the details relating to females.

Posoško staroverstvo was not only a religion. It was also the way of life in total freedom respecting also the freedom of the others.

There was worshipped only one god, the goddess Nikrmana or Velča mat or Velika mat [The Great Mother]. There was worshipped also a lot of holy spirits (Prh, zdravilec Belin, nadduh, dobri duh, črni duh, podzemni duh, vodni duh, deževni duh, gozdni duh, veterni duh, ognjeni duh, etc) [Prh, Belin the healer, head-spirit, good spirit, black spirit, sub-soil spirit, water spirit, rain spirit, forest spirit, wind spirit, fire spirit, etc.].

The good spirit created the Sun, the sky, the day and the man. The black spirit created the Moon, the Earth, the night, and the female. 
The creation of the world proceeded as follows: Sometimes in the timeless time lived Nikrmana in the non-world, where shined many stars, moons and suns. The life was there rich and diverse. Because there was not enough room, Nikrmana planned to move part of that somewhere else. She recalled to her mind the Earth, where the darkness dominated and she sent there few stars. To know the effect she sent there the golden eagle. Upon return, the golden eagle reported that part of the Earth is still too dark. She sent there an additional moon. After the next visit the golden eagle reported that the moon is unsure since there shines sometimes only a half of it, next time the whole, the third time the moon is not there since it throws light to other parts of the Earth. To solve the lighting of that part of the Earth Nikrmana sent there the sun. Then the eagle reported that there is plenty of light. During the next days, Nikrmana sent big, heavy clouds full of water. They circulated for weeks above that part of the Earth and wetted it so that there appeared the rivers Soča, Idrija, Bača and other ones, as well as many brooks and springs. The thunderbolts brought there the fire. When there was enough water, Nikrmana sent there many white clouds full of seeds of diverse plants and trees. In order that the sowing would be successful there came to help the vetrni duh [wind spirit]. Soon the Earth became green and overgrown. It was the time for the migration of all kinds of animals from the non-world. There were formed tens of rainbows of all sizes, which helped the animals to drop slowly onto meadows, forests, brooks and rivers. There were lacking only the people, therefore Nikrmana sent two young pairs on a big red cloud, which slowly let off to the Earth. When the cloud arrived close to the present village Vogrinki, both pairs prepared to get out the cloud. As one pair got out, a strong wind started to blow and pushed the cloud east, beyond the village Trebuša. There the cloud touched the Earth and the second pair could exit. After the offspring of the two pairs met and mixed, there were formed the present inhabitants at the rivers Trebušica, Idrijca, Bača and Soča.

There were given feminine names to the rivers and masculine names to the brooks flowing into them. Their confluences were considered to have special healing properties.

For prevention from iddle natural and spiritual influences served in this region a number of features named tročan (a triangular feature, especially a rectangular triangle), where in the corners of the highest-level tročan there were the holy hilltops, holy precipisses, or holy caves. In the corners of a lower level tročan there were also holy trees (vrhini), holy rocks, especially those called matjar (pron. ma:tyá:r), as well as other holy stones. The matjars had their own names.

There were several levels of the tročan features, from the regional ones to the local ones, e.g. of each building, and a lower level tročan was placed in accordance to the higher-level ones. The buildings were oriented in accordance to the higher-level tročan.

For the same reason served kačje glave i.e. special stones in form of the snake-head into which the holes for the eyes were drilled and filled with one or another special material.

The most important materials in this staroverstvo were stone and wood.

There were worshipped also some holy snakes, especially bele kače [white snakes]. Nonpoisonous snakes, especially the grass snake, served as home pets, which in the dwelling places, larders and around them were catching mice, cockroaches, poisonous snakes and other unwanted small animals, but did not eat or spoil the stored foodstuffs and were not harmful to people and domestic animals. The oral tradition does not link them to the arrival of agriculture, so it seems that the use of them was a necessity already at the time of hunters/gatherers.

They believed into higher powers and higher worlds. Especially important were the third power and the fifth power as well as the third world and the fifth world.

They believed in reincarnation. Those who lived in accordance with the rules of staroverstvo could decide by themselves into which being goes his/her zduhec [the soul] after their death. The choice was often a bird, especially an eagle, a bat, a butterfly, a dragonfly, etc. There was also possible to go to the third or finely to the fifth world. In the fifth world there always shines the sun and there is eternal spring. However, it was not possible to go out the fifth world to other worlds. This indicates some similarity with the Indic nirvana.

After the zduhec left it, the body of the deceased was no more important. After its burial, the grave was possibly marked with a stone, rarely visited and not adorned.

The people used to respect the seven commands:

- Respect yourself and equally all the people.

- Do not take what belongs to the others unless you are in danger of life, but take only enough to survive.

- Kill only when you and your people are attacked.

- Work so much that you live decently. Help generously those who cannot do this.

- Honesty is the greatest virtue of a man. Lie is the strongest poison that kills. 
- Without love, there is no life.

- Respect your own language and the habits of your ancestors.

The faithful persons, especially those of higher rank, were obliged to visit holy places each year. For males that was a holy mountain, e.g. the Jelenk. For females there served this purpose some holy caves. Everyone should bring from time to time his gift to one or another holy place in his vicinity.

They had their own regional organizations, the borders of which were defined by natural features, which were not easy to cross, e.g. deep valleys, high mountains. The regional leader was dehnar. He was first of all a spiritual leader, helping or advicing the people, suggesting a solution in the case of conflict.

Dehnar was helped by the three zapriseženi [the sworn in]. He selected two of them, whereas the community elected the third one. Before he died, dehnar decided who of the zapriseženi is the most appropriate to become the next dehnar. He was protected by the crna vahta [black guard]. The dehnarji (dehnars of the neighboring communities) gathered from time to time on a holy mountain to solve the problems appearing within their communities or between them.

This Old Religion was tolerant to the Christianism. However, since the Christians persecuted them for centuries, they were living in a deep illegal situation and dehnar was mainly helping and advising the people.

\section{Kraško staroverstvo - The Pre-Christian Religion in the Karst Region}

Kras - the Karst region is in the southwest part of Slovenia near the city Triest (on the Map 1 it is the light blue area below the mark GO in the yellow ellipse). About the pre-Christian religion in that region reported Čok $(2012,2016)$. Hrobat Virloget (2016) discussed it in view of the East Slavic pre-Chrisitian religion.

There were mentioned the deities (Triglav, Deva, Devač, Kres, Svarožič, Dajbog (Dajbugec), Makurška, and Mora), the beings (Tntava, Vedomec, Besi, Vilež, Štrige, Šembilja, and Krvavo stegno), the important toponyms (Triglavca, Trhlovca (Terglouca, Triglouca), Čuopa, Gluhi du, Uruće, Kres, Črne bukve, Trebenski kamen, Sodna jama), several rituals, spells, bewitchments and dewitchments, fairy tales, etc.

\section{Discussion}

The characteristics of the Posoško staroverstvo [the Old (pre-Christian) religion around the Soča River valley] were for example the single female god vs. male spirits, female rivers vs. male brooks, the basic importance of rocks and trees, of stone and wood, the religion knowledge and practice of females separate from that of males. They indicate a very old origin of it, in the times of matriarchate and Paleolithic. The choice of stones indicates the continuity of the Stone Age tradition since there were revered and used such stones as they were observed in finds from the Stone Age.

In view of the independent novel observations as put together by Perdih $(2013,2016,2018,2019,2021)$ it is indicated that the roots of the Posoško staroverstvo derive from more than 70,000 years ago in this and surrounding regions. The independent novel observations are i.a.

- The cosmogenic mega-tsunami of 71,000 to 57,000 years ago, most probably about 68,000 years ago, coincident with MIS 4 (Yurkovets, 2015, Yurkovets \& Vasilenko, 2017), which devastated most of the continents but leaved in Europe intact the area from the Alps till the Carpathian mountains including the three regions of present Slovenia mentioned above, cf. Perdih (2018, p. 20, Map 2);

- The observation in old skeletons across Europe of the $\mathrm{Y}$ chromosome haplogroups (in parentheses the approx. time of their formation (YFull), years ago): BT $(130,700)$, CT $(88,000), \mathrm{C}(65,900), \mathrm{F}(65,900)$, HIJK $(48,500)$, IJK $(48,500)$ as well as IJ (47,200), I (42,900) reported by Fu et al. (2016), Mathieson et al. (2017),. Lipson et al. (2017), Olalde et al. (2018).

These authors reported in aDNA in Europe the observation of the $\mathrm{Y}$ chromosome haplogroups of the almost whole series from BT to I, i.e.. $\mathrm{BT}>\mathrm{CT}>>\mathrm{F}>>\mathrm{HIJK}>\mathrm{IJK}>\mathrm{IJ}>\mathrm{I}$.

On the other hand, individuals having the haplogroup BT lived in Europe still about 5,000 years ago, those having the haplogroup CT still about 4,000 years ago, and those having the haplogroup IJ still about 7,000 years ago (Mathieson et al. 2017).

Slovenia was populated in Paleolithic and later (Laharnar, 2018). There have been observed in Slovenia also the Mesolithic tools even high in the mountains.

During the Last Glacial Maximum the snow-line in Slovenia was at the height of about 1,700 $\mathrm{m}$ above the sea level with glaciers in the shady valleys, whereas the lowlands of Slovenia were part of the Adriatic refuge resp. the Balkan refuge. 
The oldest archaeological finds were observed in Slovenia in the Divje babe [Wild Hags] cave in western Slovenia, exactly in the region of the Posoško staroverstvo.. There was excavated i.a. an about 60,000 years old flute made of a bear bone. Dimkaroski (2014) was able to display using it a scale of 37 semitones. Due to the tools accompanying the flute, Brodar (1999) ascribed it to be made by modern humans, who according to Yurkovets and Vasilenko (2017) would have survived in this region the cosmogenic mega-tsunami of about 68,000 years ago. This sophisticated flute made of bone indicates that simpler flutes made of bark, wood and similar perishable materials were in use by humans already much earlier.

The old religion Posoško staroverstvo was practicized in the region, where there existed the oral tradition about the Slovene queen Vida, who together with her troops survived in the Landarska jama [the Cave of Landar] the attacks of the warriors of Attila the Hun. This happened around $450 \mathrm{AD}$, i.e. a century before the alleged arrival of Slavs there. In addition, in the Slovene dialect of this region Kurkina (1996) noticed very archaic Slavic characteristics.

Kraško staroverstvo - the Karst old religion has besides some characteristics of the Posoško staroverstvo also several eastern Slavic pre-Christian religious characteristics. Since the agriculture arrived Slovenia first into the Karst region about 7,500 years ago (Velušček, 2014), there is the question whether the eastern Slavic pre-Christian religious characteristics arrived into the Karst region as well as into the Eastern Europe with agriculture from the Near East. Archaeological data (Turk, 2018) indicate that many hill-forts in this region started to be built about 4,500 years ago. This is coincident with the advance of the Bell Beaker culture and the Y chromosome haplogroup R1b-L23-L151 people into the Western Europe. The Slovene oral tradition of Kralj Matjaž [King Mathias], who fought the enemies intruding Slovene territories from west (Stele, 2005) is coincident as well.

Regarding the Dolenjsko staroverstvo [the pre-Christian religion in the region of Lower Carniola] and the hill-fort bird-hill pairs observed there, Sever $(2003,2004,2008,2009,2013,2017)$ supposed that it lasted continuously from the Iron Age on, when the region was rich due to the iron production. However, there were erected several hill-forts already about 6,500 years ago (Turk, 2018). This was contemporary with the destructions on the territory of present Bulgaria (Ivanova, 2006). In Dolenjska [Lower Carniola], there existed also the oral tradition about the very dangerous dog-head warriors and werewolfs endangering the inhabitants (Jurčič, 1865). The small amount of the Y chromosome haplogroup R1b* in this region only (Zupan, Vrabec, \& Glavač, 2013) indicates the intrusions and robbing of the Y chromosome haplogroup R1b people living in the regions between the Volga river and the Black Sea, where later the Yamna culture was developed by their descendants having the haplogroup R1b-L23-Z2103. In the western Slovenia, i.e. in the region of Posočje and Kras, the inhabitants erected the hill-forts later, after about 4,500 years ago (Turk, 2018). There are observed among others the now west-European haplogroups R1b-L23-L151-U152 resp. R1b-L23-L151-U108 (Zupan et al. 2013), deriving from south of the Alps resp. north of the Alps, comparable to Zieger and Utz (2020) for the situation in Schwitzerland. These haplogroups were formed after the arrival of the Y chromosome haplogroup R1b-L23-L151 people across the northern Africa into the western Europe.about 4,800 years ago (Klyosov, 2016-2019).

The remnants of the old pre-Christian religion in different parts of Slovenia are different from the eastern Slavic pre-Christian religion. Like the other data (Perdih, 2018) they indicate that there was no arrival of Slavs into the territory of the present Slovenia in the $6^{\text {th }} / 7^{\text {th }}$ Century AD but that the Slovenes were the aboriginal population in Slovenia and elsewhere in Europe as well.

The available data allow presenting the following course of events in Slovenia:

- Survival about 68,000 years ago of people having the Y chromosome haplogroups BT, CT, CF and the mitochondrial haplogroup U.

- Formation of the Y chromosome haplogroup I about 43,000 years ago.

- About 20,000 ago the formation of the Y chromosome haplogroups R1a and R1b in Central Asia.

- Survival of the Last Glacial Maximum and subsequent spread of the Y chromosome haplogroup I people across the rest of Europe.

- Movement of people having the Y chromosome haplogroup R1b from Central Asia west till the middle Volga River in present Russia about 13,000 years ago and sending the spies as far as Western Europe. Development of the pre-Kurgan and Kurgan cultures.

- Movement of people having the Y chromosome haplogroup R1a from Central Asia west till the Near East. Their appearance in the northern part of the Central Europe as the bearers of the Corded Ware culture. Their bovine pastoral way of life (Skulj, Sharda, Narale \& Sonina, 2006) is indicated up to that time and later also elsewhere.

- After about 8,000 to 6,000 years ago, arrival of agriculture into Central Europe. The bearers were mainly males having the Y chromosome haplogroup G2a and females having several mt-haplogroups observed now. Development of 
metallurgy there.

- In some areas mixing with previous inhabitants and development of new cultures.

- About 6,500 to 5,900 intrusions of the Y chromosome haplogroup R1b people from the Eastern Europe into the territory of present Bulgaria, including to the eastern Slovenia. Destruction of the lowland settlements, eradication of most of the Y chromosome haplogroup G2a people, and moving part of them, especially the miners and metallurgists to the east of the Black Sea. As the defense against them, the erection of hill-forts in eastern and central Slovenia.

- Subsequent expansion of the Y chromosome haplogroup R1b people from the Eastern Europe south as far as Egypt and Central Africa, and across the northern Africa west, arriving the Iberia about 4,800 years ago forming there the Bell Beakers culture.

- About 4,500 to 3,500 years ago their expansion north across the Western Europe and intrusions into the Central Europe including the western Slovenia and the Pannonian Plane. Eradication of previous males wherever possible.

- About 4,100 years ago arrival into Slovenia of the Y chromosome haplogroup R1a people, the bearers of the Corded Ware culture from the north-central Europe.

- About 3,000 years ago the Iron Age and the growth of the Slovene population.

- Between 2,200 and 1,900 years ago the Roman conquest of Slovenia and the Balkans. Gradual flights of parts of the inhabitants north and east across the Carpathian Mountains. Decrease of the previous population.

- Towards the end of the $5^{\text {th }}$ Century AD the retreat of the Roman population into Italy. After 530 AD arrival of Langobards as the Byzantine federati.

- After the departure of Langobards into present Italy in 568 AD, the Slovenes got free. However, their organization was only local without a central government. They were so depopulated that they could not resist for long the occupation by Avars, Franks, Hungarians, and Venetians.

- Subsequently, the population growth including some influx of the Y chromosome haplogroup R1b and other people.

- No arrival of Slavs from the east, except a small militarily organized part of ancestors of present Croats and Serbs around $630 \mathrm{AD}$ who imposed subsequently their own identity to the previous inhabitants.

- In 1991 AD, Slovenia liberated forming an independent state.

\section{Conclusions}

Presented are the known details of the staroverstvo, i.e. about the Old Religion, the pre-Christian religion in three regions in Slovenia. Staroverstvo was practicized in secret till recently and some traces of it are still perceived and researched. The most archaic of them is the Posoško staroverstvo - the Old Religion around the upper Soča River valley. For it is characteristic the single, female god, the Great Mother, a number of spirits, the importance of triangular features, rocks, caves, stone and wood, of way of life in peace, of reincarnation of souls. The Kraško staroverstvo - the Old Religion in the Karst region is intermediate between it and the East Slavic pre-Christian religion. In it is indicated the influence of the arrival of agriculture about 7,500 years ago. The Dolenjsko staroverstvo - the Old Religion in Western Lower Carniola reflects the Iron Age situation. Characteristic for it is the revering of waters as well as the bird-hills near the hill-forts. The hill-forts started to be erected on the intrusions from east of the Y chromosome haplogroup R1b* people about 6,500 years ago. The bird-hills served the birds, which would carry the soul of the deceased into the other world, possibly onto the other side of the moon.

These three types of staroverstvo in Slovenia indicate that the Slovenes are the descendants of the aboriginal population of Slovenia. In Slovenia are present the males having the aboriginal European Y chromosome haplogroup I. The Y chromosome haplogroup R1a people arrived Slovenia about 4,100 years ago as the bearers of the Corded Ware culture. The Y chromosome haplogroup R1b people arrived Slovenia in several waves. The Y chromosome haplogroup R1b* people arrived about 6,500 years ago from east. The Y chromosome haplogroup R1b-U152 people were arriving after about 4,500 years ago up to recently from west and the Y chromosome haplogroup R1b-U108 people from north. These data are in line with the indication of the staroverstvo that there is no trace of the migration of Slavs into Slovenia in the $6^{\text {th }} / 7^{\text {th }}$ Century AD from east of the Carpathian Mountains. Thus, the ancestors of Slovenes were aboriginal in Slovenia.

\section{Acknowledgement}

Devoted to the memory of the late Leopold Sever and Pavel Medvešček - Klančar.

\section{References}

Baš, A. (2004). Slovenski etnološki leksikon [The Slovene ethnologic lexicon], Ljubljana: Mladinska knjiga.

Brodar, M. (1999). Die Kultur aus der Höhle Divje babe 1. Arheološki vestnik, 50, 9-57; 
http://av.zrc-sazu.si/Si/50/Brodar50.html

Čok, B. (2012, 2016). V siju mesečine [In the moonshine], Ljubljana: Založba ZRC (Studia mythologica Slavica Supplementa, Supplementum 5, Kropej Telban, M., Pleterski, A., \& Nartnik, V., Eds.),

Dimkaroski, L. (2014). Glasbena raziskovanja piščali. Od domneve do sodobnega glasbila [Musical research of the flute. From presumption to the modern musical instrument]. In I. Turk (Ed.), Divje babe I, 2. del (pp. 205-222). Ljubljana: Opera Instituti Archaeologici Sloveniae 29. https://doi.org/10.3986/9789610503446

Fu, Q., Posth, C., Hajdinjak, M., Petr, M., Mallick, S., Fernandes, D, ... Reich, D. (2016). The genetic history of Ice Age Europe. Nature, 534, 200-205. https://doi.org/10.1038/nature17993

Hrobat, V. K. (2016). Outlines of the mythic characters in the villages of Lokev and Prelože in the context of Slavic mythology. In B. Čok (2016), V siju mesečine [In the moonshine] (pp. 173-182). Ljubljana: Založba ZRC (Studia mythologica Slavica - Supplementa, Supplementum 5, Kropej Telban M, Pleterski A, \& Nartnik V, Eds.).

Ivanova, M. (2006). Tells, Invasion Theories and Warfare in Fifth Millennium B.C. North-Eastern Bulgaria, Journal of Conflict Archaeology, 2, 33-48, https://doi.org/10.1163/157407706778942277

Jurčič, J. (1865). Deklica in psoglavci [The girl and the dog-head warriors], Slovenski glasnik, 239. As well as: Jurčič, J. (1947). Zbrano delo 1 (M. Rupel, Ed.), (pp. 16-18; 52). Ljubljana: Državna založba Slovenije.

Klyosov, А. А. (2016). ДНК-генеалогия от A до T [DNA Genealogy from A to T]. Москва: Книжный мир.

Klyosov, A. А. (2017). История ариев и эрбинов. Европейский Запад против европейского Востока [History of Aryans and Arbins. European West against European East]. Москва: Концептуал.

Klyosov, A. A. (2018). DNA Genealogy. Scientific Research.Publishing

Klyosov, A. А. (2019). ДНК-генеалогия славян: происхождение и история [DNA-genealogy of Slavs: origin and history]. СПб.: Питер.

Kurkina, L. V. (1996). О лексических архаизмах Толминского диалекта [On the lexical archaisms in the dialect of Tolmin], Razprave II. razreda, Ljubljana: Slovenska akademija znanosti in umetnosti (Dissertationes classis II, Academia scientiarum et artium Slovenica), 15, 35-46.

Lipson, M., Szécsényi-Nagy, A., Mallick, S., Pósa, A., Stégmár, B., Keerl V., ... Reich, D. (2017). Parallel palaeogenomic transects reveal complex genetic history of early European farmers. Nature, 551, 368-372. https://doi.org/10.1038/nature24476

Laharnar, B. (2018). Gradišča med Nanosom in Snežnikom [Hill-forts between Nanos and Snežnik]. In: D. Vončina (Ed.), Gradišča v osrednji in zahodni Sloveniji [Hill-forts in central and western Slovenia] (pp. 27-47). Gorjansko: Zavod Krasen Kras.

Mathieson, I., Lazaridis, I., Rohland, N., Mallick, S., Patterson, N., Roodenberg, S. A., ... Reich, D. (2015). Eight thousand years of natural selection in Europe. Nature, 528, 499-503. https://doi.org/10.1038/nature16152

Medvešček, P., \& Podobnik, R. (2006). Let v lunino senco [The flight into the Moon's shadow], Nova Gorica: Taura.

Medvešček, P., \& Skrt, D. (2014). Staroverstvo in staroverci: Katalog etnološke zbirke Pavla Medveščka [Old religion and its adherents: Catalogue of the ethnologic collection by Pavel Medvešček]. Nova Gorica: Goriški muzej Kromberk.

Medvešček - Klančar, P. (2015). Iz nevidne strani neba: razkrite skrivnosti staroverstva [From the invisible side of the sky: The secrets of the Old Religion uncovered]. Ljubljana: Založba ZRC (Studia mythologica Slavica Supplementa, Supplementum 12, M. Kropej Telban, A. Pleterski, \& V. Nartnik, Eds.). https://doi.org/10.3986/9789612548490

Medvešček, P., \& Skrt, D. (2016). Staroverstvo in staroverci: Katalog etnološke zbirke Pavla Medveščka 2 [Old religion and its adherents: Catalogue of the ethnologic collection by Pavel Medvešček 2]. Nova Gorica: Goriški muzej Kromberk.

Olalde, I., Brace, S., Allentoft, M. E., Armit, I., Kristiansen, K., Rohland, N., ... Reich, D. (2017). The Beaker Phenomenon and the Genomic Transformation of Northwest Europe. Nature, 555, 190-196. https://doi.org/10.1038/nature25738

Perdih, A. (2013). Izvor Slovencev in drugih Evropejcev [Origin of Slovenes and other Europeans]. Ljubljana: Založništvo Jutro, www.jutro.si

Perdih, A. (2016). Izvor Slovencev in drugih Evropejcev [Origin of Slovenes and other Europeans] (2 ${ }^{\text {nd }}$, revised ed.). 
Ljubljana: Založništvo Jutro, www.jutro.si

Perdih, A. (2018). Continuity of European Languages from the Point of View of DNA Genealogy. International Journal of Social Science Studies, 6, 18-32. https://doi.org/10.11114/ijsss.v6i1.2809

Perdih, А. (2019). Past events on the territory of present Slovenia. Вестник Академии ДНК-генеалогии [Рrосееdings of the Academy of DNA Genealogy], 12, 1785-1794.

Perdih, A. (2021). Izvor Slovencev in drugih Evropejcev [Origin of Slovenes and other Europeans] (3rd, revised ed.). Ljubljana: Založništvo Jutro, www.jutro.si

Sever, L. (2003). Iskal sem prednamce [I Looked for Our Forefathers]. Turjak.

Sever, L. (2004). Pozabljene vode [Forgotten Waters]. Ivančna Gorica: Turistično društvo.

Sever, L. (2008). O imenih našega vodovja [The Names of Our Waters]. Zbornik občin Grosuplje, Ivančna Gorica. Dobrepolje, 25, 129-139.

Sever, L. (2009). Prazgodovinski svatje in mi [Prehistoric Wedding Guests and Us]. Ivančna Gorica: Turistično društvo.

Sever, L. (2013). Tičnice iz naravoverja: zanesljivi kažipoti v slovensko prazgodovino [Bird-hills from Natural Religion: Reliable Waymarks of Slovene Prehistory]. Male Lipljene.

Sever, L. (2017). Male Lipljene: vas ki je ravno prav [Male Lipljene: the Just Right Village]. Male Lipljene.

Skulj, J., Sharda, J. C., Narale, R., \& Sonina, S. (2006). 'Lexical Self -Dating' Evidence for a Common Agro-Pastoral Origin of Sanskrit 'Gopati', 'Gospati' and Slavic 'Gospod', 'Gospodin' Meaning Lord/Master/Gentleman more than 8,000 Years Ago. Vedic Science, 8, 5-24; as well as: Zbornik četrte mednarodne konference Evropski staroselci, Jutro, Ljubljana, 40-58; http://www.korenine.si/zborniki/zbornik06

Stele, F. (2005). Slovenija z dlani. Komenda.

Šavli, J. (2008a). Zlata ptica: Bajeslovje Slovencev, duhovna dediščina Karantanije [Golden Bird: Mythology of Slovenes, the spiritual heritage of Carantania]. Bilje: Studio RO - Humar

Šavli, J. (2008b). Zlati cvet: Bajeslovje Slovencev, duhovna dediščina Karantanije [Golden Blossom: Mythology of Slovenes, the spiritual heritage of Carantania]. Bilje: Studio RO - Humar

Turk, P. (2018). Neolitska gradišča v osrednji Sloveniji [Neolithic hill-forts in central Slovenia]. In: D. Vončina (Ed.), Gradišča v osrednji in zahodni Sloveniji [Hill-forts in central and western Slovenia] (pp. 13-25). Gorjansko: Zavod Krasen Kras.

Velušček, A. (2014). Absolutna kronologija slovenskega neo- in eneolitika - prispevek za razpravo [Absolute Chronology of the Slovenian Neo- and Eneolithic - Contribution to the Discussion]. In B. Teržan \& M. Črešnar (Eds.), Absolutno datiranje bronaste in železne dobe na Slovenskem [Absolute Dating of the Bronze and Iron Ages in Slovenia] (629-644). Ljubljana: Narodni muzej Slovenije, Filozofska fakulteta Univerze v Ljubljani.

YFull, http://www.yfull.com/tree/

Yurkovets, V. P. (2015). Климатическая катастрофа гаплогруппы «Бета» [Climatic catastrophe of the haplogroup «Beta»]. Вестник Академии ДНК-генеалогии [Proceedings of the Academy of DNA Genealogy], 8, 376-432.

Yurkovets, V. P., \& Vasilenko, S. I. (2017). ДНК-генеалогия, палеоклимат и геоморфология. Гидродинамический карст [DNA Genealogy, Paleoclimate and Geomorphology. Hydrodynamic Karst]. Вестник Академии ДНК-генеалогии [Proceedings of the Academy of DNA Genealogy], 10, 1412-1442.

Zieger, M., \& Utz, S. (2020). The Y-chromosomal haplotype and haplogroup distribution of modern Switzerland still reflects the alpine divide as ageographical barrier for human migration. Forensic Science International: Genetics, 48, 102345. https://doi.org/10.1016/j.fsigen.2020.102345

Zupan, A., Vrabec, K., \& Glavač, D. (2013). The paternal perspective of the Slovenian population and its relationship with other populations. Ann Hum Biol, 40, 515-526. https://doi.org/10.3109/03014460.2013.813584

\section{Copyrights}

Copyright for this article is retained by the author(s), with first publication rights granted to the journal.

This is an open-access article distributed under the terms and conditions of the Creative Commons Attribution license (http://creativecommons.org/licenses/by/4.0/). 